\title{
Effect of Fluoride on Tooth Erosion Around Orthodontic Brackets
}

\author{
Erika Machado CALDEIRA \\ Tatiana Kelly da Silva FIDALGO \\ Paula PASSALINI \\ Mariana MARQUEZAN \\ Lucianne Cople MAIA \\ Matilde da Cunha Gonçalves NOJIMA \\ Department of Pediatric Dentistry and Orthodontics, Dental School, \\ UFRJ - Universidade Federal do Rio de Janeiro, Rio de Janeiro, RJ, Brazil
}

\begin{abstract}
The aim of the present study was to evaluate the effect of fluoride in prevention of tooth erosion around orthodontic brackets under erosive challenge. Edgewise brackets were bonded with Transbond ${ }^{\mathrm{TM}}$ XT composite on vestibular surface of 40 bovine incisors. The teeth were assigned to 4 groups ( $n=10)$ : G1: Remineralizing saliva; G2: Erosive challenge; G3: Experimental group submitted to topical application of neutral fluoride gel $(2 \% \mathrm{NaF})$ before erosive challenge; G4: Experimental group submitted to three daily applications of fluoride dentifrice (PFM $1500 \mathrm{ppmF}$ ) during erosive challenge. After 14 days of erosive challenge, direct visual and tactile examination were performed by two calibrated and trained examiners (Kappa $=0.867)$. The following scores were used: $0=$ Intact enamel, 1 = Demineralized enamel without cavity, $2=$ Demineralized enamel with cavity, $3=$ Remineralized enamel without cavity, 4 = Remineralized enamel with cavity. Kruskal-Wallis and Mann-Whitney tests were applied to determine erosion levels, establishing a confidence interval of $95 \%(\mathrm{p}<0.05)$. G2 and G3 presented $100 \%$ of score 2 , with large cavities, presenting rough and opaque surface. G4 showed $50 \%$ of score 3 and $50 \%$ of score 4 . Considering the studied conditions, it was found a significant difference between G2 and G4 and between G3 and G4 ( $<<0.01$ ). By contrast to single application of neutral fluoride gel, the high frequency of use of fluoride at low concentration had a great influence during the dynamics of erosion.
\end{abstract}

Key Words: tooth erosion, dental enamel, fluorides, primary prevention, orthodontic brackets.

\section{INTRODUCTION}

The incidence of dental caries has declined in developed countries (1) followed by the increase of other dental lesions caused by extrinsic factors, such as tooth erosion. Tooth erosion is the loss of mineral tooth substrate by chemical processes not involving bacteria (2). This kind of wear is caused by the contact of enamel substrate with acidic foods and drinks, especially due to greater consumption of fizzy and soft drinks $(3,4)$.

The erosive potential of a substance is not exclusively dependent on $\mathrm{pH}$ value and type of acid, but is also strongly influenced by its titrable acidity, calcium-chelation properties, mineral content and by adhesion to the dental surface $(3,5)$. In this context, fixed orthodontic appliances acts as an additional retention surface $(6,7)$. In an attempt to fulfill an increasingly aesthetic demand, the use of orthodontic appliances are increasing (8).

Different strategies have been used for the prevention and treatment of tooth erosion and topical application of fluoride is one of them. However the preventive action on dental erosion is still controversial (9-11). Therefore, it seems important to evaluate the influence of fluoride compounds in the prevention of tooth erosion with orthodontic appliances under conditions that reproduce oral environment. Thus, the aim of the present study was to evaluate the effect of fluoride in the prevention of tooth erosion around orthodontic brackets under erosive challenge. 


\section{MATERIAL AND METHODS}

\section{Sample Preparation}

Forty bovine incisors were sectioned along the cementoenamel junction and their crowns were embedded in epoxy resin with the buccal surface facing the glass plate. Silicon carbide papers with successive grits (\#180, \#400 and \#600;3M, Rio de Janeiro, RJ, Brazil) were used to remove excess resin and expose the bonding area. After this, the coronal portion was subjected to prophylaxis with prophylactic rubber cups (KG Sorensen, Rio de Janeiro, RJ, Brazil) at low speed, and extra-thin pumice (S.S. White, Rio de Janeiro, RJ, Brazil) for $5 \mathrm{~s}$. Samples were washed in deionized water for $15 \mathrm{~s}$ and dried using an oil-free air jet and water vapor for the same period of time.

The bonding area of each crown was located in the most central area of the middle third of bovine incisor buccal surface. Maxillary central incisor brackets (Edgewise system; Morelli, Sorocaba, SP, Brazil) were bonded with Transbond ${ }^{\mathrm{TM}}$ orthodontic light-cured resin (3M Unitek, Monrovia, CA, USA) according to the manufacturer's instructions. The teeth were assigned to 4 groups ( $n=10)$ : $\mathrm{G} 1$ (negative control): neutral saliva (no cariogenic challenge); G2 (positive control): $\mathrm{pH}$ cycling (erosive challenge without fluoride application); G3: experimental group subjected to topical application of neutral fluoride gel $(2 \% \mathrm{NaF})$ before the erosive challenge; G4: experimental group subjected to three daily applications of a fluoride dentifrice $(1,500 \mathrm{ppmF})$ during the erosive challenge.

\section{Erosive Challenge Model}

The artificial saliva solutions was based on Lamers et al. (12) and Damato et al. (13). The pHcycling dynamics was based on Queiroz et al. (2008) (14), but with the following modifications to induce erosive lesions: no fluoride in the solutions, reduction of the immersion time in demineralizing saliva and longer $\mathrm{pH}$-cycling to induce tooth erosion. The immersion time of the teeth in demineralizing saliva $(2 \mathrm{~h})$ was based on the remineralizing $\mathrm{pH}$-cycling dynamics described by Queiroz et al. (14). The $2 \mathrm{~h}$ was chosen instead of 4 $\mathrm{h}$, since the absence of fluoride supplement increases the demineralizing potential of this $\mathrm{pH}$-cycle model. The $\mathrm{pH}$ cycling consisted in the alternation of groups in artificial remineralizing/neutral saliva (12) (1.54 $\mathrm{mmol} / \mathrm{L}$ calcium, $1.54 \mathrm{mmol} / \mathrm{L}$ phosphate, $20 \mathrm{mmol} / \mathrm{L}$ acetic acid and $0.308 \mathrm{~g}$ ammonium acetate, adjusted to $\mathrm{pH} 7.0$ with potassium hydroxide; VETEC, Rio de Janeiro, RJ, Brazil) and demineralizing saliva (13) (3 $\mathrm{mmol} / \mathrm{L}$ calcium, $3 \mathrm{mmol} / \mathrm{L}$ phosphate, $50 \mathrm{~mL} / \mathrm{L}$ acetic acid and $0.308 \mathrm{~g}$ ammonium acetate; VETEC) with $\mathrm{pH}$ adjusted to 4.5 with sodium hydroxide.

The groups remained in demineralizing saliva daily for $22 \mathrm{~h}$ consecutively, were rinsed with deionized water, and then kept in contact with remineralizing saliva for $2 \mathrm{~h}$, completing a cycle of $24 \mathrm{~h}$ (14). During the period of $\mathrm{pH}$ cycling, the specimens were maintained in an incubator (Fanem Ltd., São Paulo, SP, Brazil), at a constant temperature of $37^{\circ} \mathrm{C}$ in order to simulate the oral environment conditions. These dynamics were reproduced for the period of 14 days, during which the artificial saliva (neutral and acid) was changed every 2 days.

\section{Mineral Loss Index}

After $\mathrm{pH}$ cycling, two trained and calibrated examiners classified macroscopically the enamel surfaces according to the mineral loss around the brackets. After drying tooth surfaces, direct visual and tactile examinations were performed under artificial illumination. The scores used were: $0=$ intact enamel; $1=$ demineralized enamel without cavity; 2 = demineralized enamel with cavity; 3 = remineralized enamel without cavity; 4 = remineralized enamel with cavity. Remineralized enamel was assumed when it presented smooth and bright surface to visual examination and erosion was assumed when the surface presented cavity

Table 1. Mineral loss index $($ Inter-examiner agreement $=0.867)$.

\begin{tabular}{lccccc}
\hline Groups & $\begin{array}{c}\text { Index 0 } \\
(\%)\end{array}$ & $\begin{array}{c}\text { Index 1 } \\
(\%)\end{array}$ & $\begin{array}{c}\text { Index 2 } \\
(\%)\end{array}$ & $\begin{array}{c}\text { Index 3 } \\
(\%)\end{array}$ & $\begin{array}{c}\text { Index 4 } \\
(\%)\end{array}$ \\
\hline G1 & RS & RS & RS & RS & RS \\
G2 & 0 & 0 & 100 & 0 & 0 \\
G3 & 0 & 0 & 100 & 0 & 0 \\
G4 & 0 & 0 & 0 & 50 & 50 \\
\hline
\end{tabular}

G1 (negative control): neutral saliva; G2 (positive control): $\mathrm{pH}$ cycling (erosive challenge without fluoride application); G3: topical application of $2 \% \mathrm{NaF}$ before the erosive challenge; $\mathrm{G} 4$ : 3 daily applications of a fluoride dentifrice during the erosive challenge. $\mathrm{RS}=$ Remineralizing saliva, did not changed the surface. 
or irregularities on visual and tactile examination.

\section{Scanning Electron Microscopy (SEM)}

G1 and the experimental groups (G2, G3 and G4) were rinsed with deionized water for debris removal. The samples were positioned on a double-faced adhesive tape on a sample chamber whose sequence was carefully recorded and was sputter-coated with palladium-gold. The samples were analyzed using a scanning electron microscope (2000 FX; Jeol Tokyo, Japan) operating at $20 \mathrm{kV}$ and the SEM images were recorded at $\times 1,000$.

\section{Statistical Analysis}

The score results were inserted in the database of the statistical program SPSS 16.0 (SPSS Inc., Chicago, IL, USA). The scores were subjected to statistical analysis by the Kruskal-Wallis and Mann-Whitney tests. The statistical tests were performed with a confidence interval of $95 \%(p<0.05)$. The inter-rater agreement Kappa test was calculated to evaluate the agreement for differential diagnosis of mineral loss index.

\section{RESULTS}

Inter-examiner kappa was 0.867 , demonstrating a good agreement in outcome measure.

Table 1 presents the surface alterations observed in groups submitted to erosive challenge, according to the mineral loss index. G1 was not subjected to $\mathrm{pH}$ cycling, thus no demineralization was detected (Fig. 1A). G2 (Fig. 1B) and G3 (Fig. 1C) presented 100\% of score 2, with large cavities with rough and opaque surfaces. G4 (Fig. 1D) showed 50\% of score 3 and 50\% of score 4 . Although $50 \%$ of G4's specimens presented small cavitation, the enamel area was remineralized, smooth and bright.

Considering the studied conditions, statistically significant difference was found among the groups ( $\mathrm{p}=0.011$; Kruskal-Wallis test). There was a significant difference between $\mathrm{G} 2$ and $\mathrm{G} 4$ ( $\mathrm{p}=0.004$; Mann-Whitney test) and between G3 and G4 ( $\mathrm{p}=0.024$; Mann-Whitney test). No statistically significant difference was found
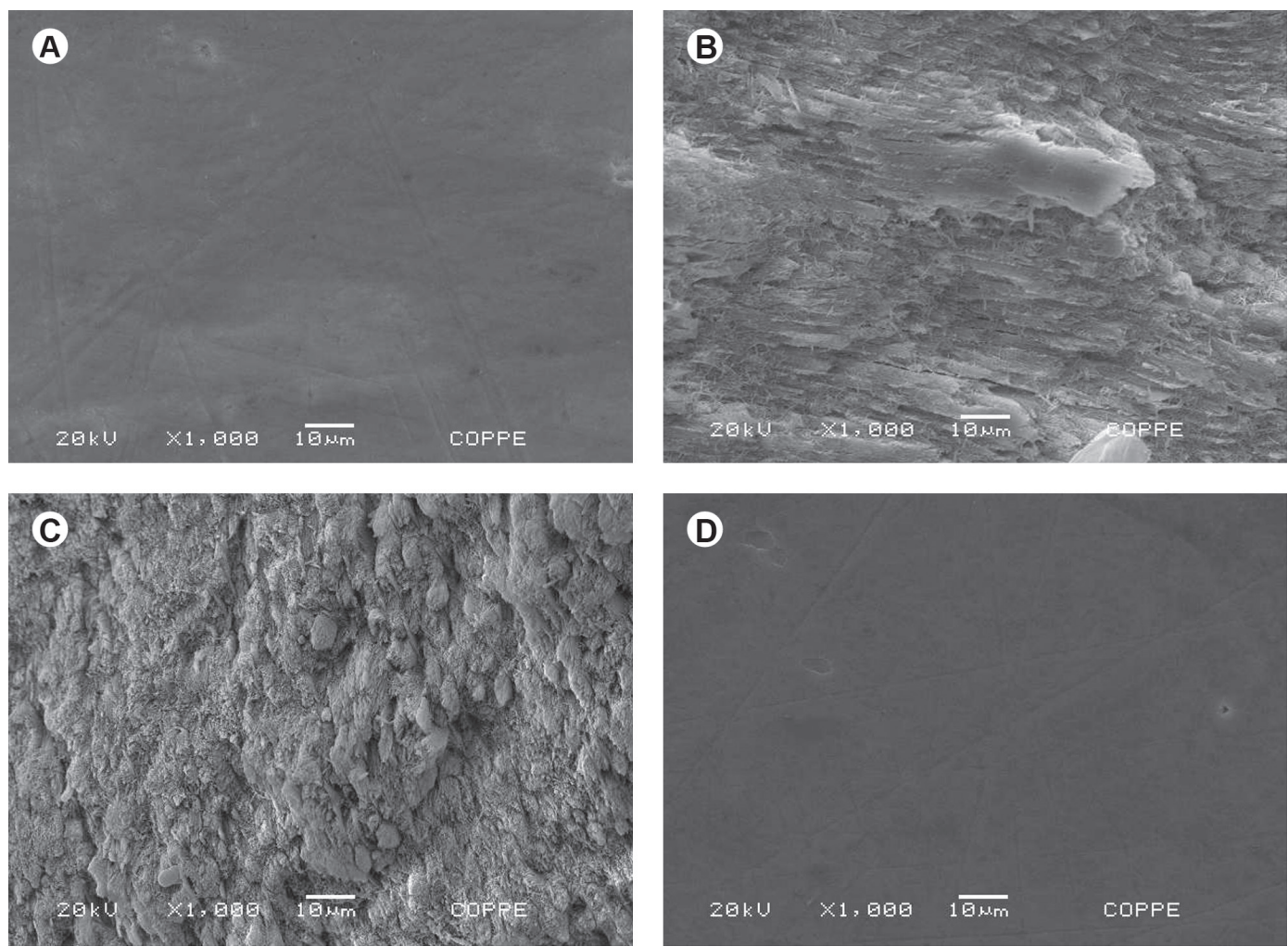

Figure 1. Representative images of the groups. A: G1 (negative control) - neutral saliva (no cariogenic challenge). B: Erosion without fluoride application (G2). C: Erosion after a single application of topical fluoride (G3). D: Remineralization and prevention of erosion after three daily applications of a fluoride dentifrice (G4). 
between G2 and G3 ( $p=0.143$; Mann-Whitney test).

\section{DISCUSSION}

Mechanical characteristics of orthodontic materials used to bond devices are frequently assessed in literature (15-17). However, the biologic effect of these materials on the teeth is also important, since orthodontic treatment should maintain the health of oral tissues $(16,18)$. In this context, this study presented erosion simulation method for in vitro orthodontic studies using $\mathrm{pH}$ cycling. The $\mathrm{pH}$ of the environment and retentive sites are factors that contribute to the retention of acidic substances in contact with the tooth substrate resulting in tooth demineralization and tooth erosion $(19,20)$. Mechanical properties of orthodontic materials are generally overlooked in the literature, and such studies are not usually conducted under conditions that simulates $\mathrm{pH}$ alterations characterizing the oral environment (21). Thus, the present study aimed to simulate in vitro erosion and evaluating the efficacy of external sources of fluoride in this process using a $\mathrm{pH}$ cycling model without fluoride in demineralizing and remineralizing solutions. The $\mathrm{pH}$ cycling is largely used to evaluate therapeutic fluoride compounds $(14,22)$ even in combination with orthodontic appliances $(7,15,18)$. However, to the best of our knowledge, this is the first study in which this method was applied to induce erosive patterns and also to evaluate the erosion preventive effect of fluoridated compounds applied on teeth with orthodontic brackets.

The present study showed that the long-term enamel exposure to acid conditions leads to higher hydroxyapatite dissolution in the absence of fluoride. In addition, the single previous application of neutral fluoride was not able to prevent dental erosion. On other hand, the fluoride dentifrice possibly acted as a demineralization inhibitor. It seems that during the demineralization dynamics, fluoride and free calcium in the artificial saliva were incorporated into the dental substrate, forming fluoridated hydroxyapatite and calcium fluoride on the dental surface (7). As fluoridated hydroxyapatite is more resistant to acid attacks (23), initial white spots of fluoride dentifrice group were remineralized and a more intense mineral loss could be prevented.

Only the fluoride dentifrice was able to prevent the formation of cavitation. The group subjected to daily fluoride dentifrice presented in $50 \%$ of samples remineralized initial white spots with the absence of cavitation in specimens, and in the remaining $50 \%$, presence of white spot remineralized with small areas of cavitation. These data suggest that under conditions of erosive challenge, the use of low-concentration and high-frequency-use fluoride home-care products has a great importance during the dynamics of tooth remineralization and prevent cavity formation.

The fixed orthodontic appliance acts as an additional retention site for the demineralizing solution that simulates erosion challenge (7). Although, Baechen et al. showed that fixed orthodontic appliances increases oral $\mathrm{F}$ retention (24), in the present study it was not able to prevent mineral loss. In addition, Rios et al. (24), in an in situ study, stated that toothbrushing can intensify the effects of an erosive challenge. Thus, a limitation of the present study was the absence of frictional force. Further studies should be conducted to evaluate the erosion preventive effect of fluoride dentifrice concomitant to the use of toothbrushing.

In order to prevent dental wear, professionals should instruct their patients regarding the possibility of acidic substances cause irreversible damage to dental hard tissue. Patients that present high risk of dental erosion, should decrease the frequency of ingestion of potentially harmful drinks and food, as well as minimize their contact time with teeth $(25,26)$. In addition, fluoride home-care products should be used as an additional prevention method. The present study demonstrated an important tool for assessing the prevention of erosion in tooth surfaces with fixed orthodontic appliances.

Based on the methodology applied in this study, it was found that a low-concentration and high-frequencyuse fluoride dentifrice was able to prevent the formation of cavities and that even under conditions simulating an erosive challenge, fluoride dentifrice possibly acted as a demineralization inhibitor.

\section{RESUMO}

O objetivo do presente estudo foi avaliar o efeito do flúor na prevenção da erosão do esmalte circunjacente a braquetes ortodônticos sob desafio erosivo. Braquetes edgewise foram colados com resina Transbond ${ }^{\mathrm{TM}}$ XT na superfície vestibular de 40 incisivos bovinos. Os dentes foram divididos em 4 grupos $(n=10)$ : G1: Saliva remineralizadora; G2: Desafio erosivo; G3: Grupo experimental submetido à aplicação tópica de flúor gel neutro (NaF a 2\%) antes do desafio erosivo; G4: Grupo experimental submetido à três aplicações diárias de dentifrício fluoretado (1500 ppmF PFM) durante o desafio erosivo. Após 14 dias de desafio erosivo, foi realizado exame visual e táctil por dois examinadores calibrados e treinados $($ Kappa $=0,867)$. Os escores utilizados foram: $0=$ Esmalte hígido, $1=$ Esmalte 
desmineralizado sem cavidade, $2=$ Esmalte desmineralizado com cavidade, 3 = Esmalte remineralizado sem cavidade, $4=$ Esmalte remineralizado com cavidade. Foram utilizados os testes de Kruskal-Wallis e Mann-Whitney para determinar os níveis de erosão, estabelecendo um intervalo de confiança de $95 \%(\mathrm{p}<0,05)$. O G2 e G3 apresentaram 100\% de grau 2, com grandes cavidades, apresentando superfície rugosa e opaca. O G4 apresentou 50\% de escore 3 e $50 \%$ de escore 4 . Considerando as condições estudadas, verificou-se uma diferença significativa entre G2 e $\mathrm{G} 4$ e entre G3 e G4 ( $<<0,01)$. Diferentemente da aplicação única de gel fluoretado neutro, a elevada frequência de utilização de dentifrício com flúor em baixa concentração apresentou grande influência durante a dinâmica de erosão.

\section{ACKNOWLEDGEMENTS}

The authors wish to thank FAPERJ for the financial support and COPPE-UFRJ for the support with the scanning electron microscopy images.

\section{REFERENCES}

1. Brown LJ, Wall TP, Lazar V. Trends in total caries experience: permanent and primary teeth. J Am Dent Assoc 2000;131:223-231.

2. Barbour ME, Rees GD. The role of erosion, abrasion and attrition in tooth wear. J Clin Dent 2006; 17:88-93.

3. Torres CP, Chinelatti MA, Gomes-Silva JM, Rizoli FA, Oliveira MA, Palma-Dibb RG, et al.. Surface and subsurface erosion of primary enamel by acid beverages over time. Braz Dent J 2010;21:337-345.

4. Lussi A, Jaeggi T, Zero D. The role of diet in the aetiology of dental erosion. Caries Res 2004;38 Suppl 134-144.

5. Lussi A, von Salis-Marincek M, Ganss C, Hellwig E, Cheaib Z, Jaeggi T. Clinical study monitoring the $\mathrm{pH}$ on tooth surfaces in patients with and without erosion. Caries Res 2012;46:507-512.

6. Baeshen H, Kjellberg H, Birkhed D. Oral fluoride retention in orthodontic patients with and without fixed appliances after using different fluoridated home-care products. Acta Odontol Scand 2010;68:185-192.

7. Passalini P, Fidalgo TKS, Caldeira EM, Gleiser R, Nojima MCG, Maia LC. Preventive effect of fluoridated orthodontic resins subjected to high cariogenic challenges. Braz Dent J 2010:21:211215.

8. Eliades T. Orthodontic materials research and applications: part 2. Current status and projected future developments in materials and biocompatibility. Am J Orthod Dentofacial Orthop 2007;131:253262.

9. Larsen MJ, Richards A. Fluoride is unable to reduce dental erosion from soft drinks. Caries Res 2002;36:75-80.

10. Magalhaes AC, Rios D, Martinhon CC, Delbem AC, Buzalaf MA, Machado MA. The influence of residual salivary fluoride from dentifrice on enamel erosion: an in situ study. Braz Oral Res 2008;22:67-71
11. Wiegand A, Attin T. Influence of fluoride on the prevention of erosive lesions - a review. Oral Health Prev Dent 2003;1:245-253.

12. Lammers PC, Borggreven JM, Driessens FC. Acid-susceptibility of lesions in bovine enamel after remineralization at different $\mathrm{pH}$ values and in the presence of different fluoride concentrations. J Dent Res 1991;70:1486-1490.

13. Damato FA, Strang R, Stephen KW. Effect of fluoride concentration on remineralization of carious enamel: an in vitro pH-cycling study. Caries Res 1990;24:174-180.

14. Queiroz CS, Hara AT, Paes Leme AF, Cury JA. pH-cycling models to evaluate the effect of low fluoride dentifrice on enamel de- and remineralization. Braz Dent J 2008;19:21-27.

15. Passalini P, Fidalgo TKS, Caldeira EM, Gleiser R, Nojima MCG, Maia LC . Mechanical properties of one and two step fluoridated orthodontic resins submitted to different $\mathrm{pH}$ cycling regimes. Braz Oral Res 2010;24:197-203.

16. Costa AR, Correr AB, Puppin-Rontani RM, Vedovello SA, Valdrighi HC, Correr-Sobrinho L, et al.. Effect of bonding material, etching time and silane on the bond strength of metallic orthodontic brackets to ceramic. Braz Dent J 2012;23:223-227.

17. Pithon MO, MV; Ruellas, ACO; Bolognese, AM; Romano, FL. Shear bond strength of orthodontic brackets to enamel under different surface treatment conditions. J Appl Oral Sci 2007; 15:127-130.

18. Fidalgo TKS, Pithon MM, dos Santos RL, de Alencar NA, Abrahao AC, Maia LC. Influence of topical fluoride application on mechanical properties of orthodontic bonding materials under pH cycling. Angle Orthod 2012;82:1071-1077.

19. Damon PL, Bishara SE, Olsen ME, Jakobsen JR. Effects of fluoride application on shear bond strength of orthodontic brackets. Angle Orthod 1996;66:61-64.

20. Kecik D, Cehreli SB, Sar C, Unver B. Effect of acidulated phosphate fluoride and casein phosphopeptide-amorphous calcium phosphate application on shear bond strength of orthodontic brackets. Angle Orthod 2008;78:129-133.

21. Lowder PD, Foley T, Banting DW. Bond strength of 4 orthodontic adhesives used with a caries-protective resin sealant. Am J Orthod Dentofacial Orthop 2008;134:291-295.

22. Qu H, Vasiliev AL, Aindow M, Wei M. Incorporation of fluorine ions into hydroxyapatite by a $\mathrm{pH}$ cycling method. J Mater Sci Mater Med 2005;16:447-453.

23. Sudjalim TR, Woods MG, Manton DJ, Reynolds EC. Prevention of demineralization around orthodontic brackets in vitro. Am J Orthod Dentofacial Orthop 2007;131:705 e701-709.

24. Rios D, Honorio HM, Magalhaes AC, Buzalaf MA, Palma-Dibb RG, Machado MA, et al.. Influence of toothbrushing on enamel softening and abrasive wear of eroded bovine enamel: an in situ study. Braz Oral Res 2006;20:148-154.

25. Serra MC, Messias DC, Turssi CP. Control of erosive tooth wear: possibilities and rationale. Braz Oral Res 2009;23 Suppl 149-55.

Received April 13, 2012 Accepted September 25, 2012 